ORIGINAL ARTICLE

\title{
Litter layer removal and implications on decomposition in a Eucalyptus stand in the Cerrado
}

\author{
Remoção da serapilheira e implicações na decomposição em povoamento de \\ Eucalyptus no Cerrado
}

Marco Bruno Xavier Valadão ${ }^{1}$ (D), Karla Monique Silva Carneiro² (D), Jonas Inkotte ${ }^{1}$ (D), Fabiana Piontekowski Ribeiro ${ }^{1}$ (1) , Maísa Isabela Rodrigues ${ }^{1}$ (D) , Bárbara Elias Reis Hodecker ${ }^{1}$ (i), Eder Pereira Miguel $^{1}$ (D), Alcides Gatto ${ }^{1}$ (1)

${ }^{1}$ Universidade de Brasília - UnB, Brasília, DF, Brasil

Universidade do Estado do Mato Grosso - UNEMAT, Nova Xavantina, MT, Brasil

How to cite: Valadão, M. B. X., Carneiro, K. M. S., Inkotte, J., Ribeiro, F. P., Rodrigues, M. I., Hodecker, B. E. R., Miguel, E. P., \& Gatto, A. (2021). Litter layer removal and implications on decomposition in Eucalyptus stand in the Cerrado. Scientia Forestalis, 49(131), e3499. https://doi.org/10.18671/scifor.v49n131.08

\begin{abstract}
Environmental impacts resulting from Eucalypts cultivation are widely debated and subordinated to justifications, often fallacious and without a scientific support. It is a fact that annual and perennial monocultures cause impacts. However, when talking about conservation and increase of organic matter in the soil, perennial crops such as Eucalypts cannot be discarded. In this context, the objective of this work was to evaluate the impact of the litter layer on leaf decomposition and physico-chemical properties in a Eucalyptus stand on Cerrado dystrophic soil. Removal of litter layer was done every two months. In forty plots; twenty non-removed and twenty of removed litter layer, data of litter fall, leaf decomposition and soil physical and chemical properties were obtained. Litter layer removal increased the leaf decomposition time of leaf decomposition and caused changes in potassium concentration and soil moisture. Through the results, it was possible to emphasize the environmental relevance of organic waste, even though coming from a perennial monoculture.
\end{abstract}

Keywords: Soil physico-chemical properties; Litter bags; Macronutrients.

\section{Resumo}

Impactos ambientais decorrentes da cultura do Eucalyptus são amplamente debatidos e subordinados a justificativas, muitas vezes, falaciosas e sem respaldo científico. É fato que monoculturas anuais e perenes causam impactos. Porém, quando se fala em conservação e incremento de matéria orgânica no solo, culturas perenes, como os povoamentos de Eucalyptus, não podem ser descartadas. Neste contexto, o objetivo deste trabalho foi avaliar, em um povoamento de eucalipto, o impacto da remoção da camada de serapilheira na decomposição foliar e nas propriedades físico-químicas de um solo distrófico do Cerrado. A remoção da camada de serapilheira ocorreu a cada dois meses. Em quarenta parcelas, vinte com a não remoção e vinte com remoção da serapilheira, foi avaliada a produção de serapilheira, decomposição foliar e propriedades físicas e químicas do solo. A remoção da camada aumentou o tempo estimado de decomposição das folhas e causou alterações na concentração de potássio e umidade do solo. Por meio dos resultados, foi possível reforçar a relevância ambiental dos resíduos orgânicos, mesmo que provenientes de monoculturas perenes.

Palavras-chave: Propriedades físico-químicas do solo; Sacolas de decomposição; Macronutrientes.

\footnotetext{
Financial support: None.

Conflict of interest: Nothing to declare.

Corresponding author: marcobrunovaladao@gmail.com

Received: 18 October 2019.

Accepted: 7 December 2020.

Editor: Paulo Henrique Müller Silva.
}

(i) This is an Open Access article distributed under the terms of the Creative Commons Attribution License, which permits unrestricted use,

c) distribution, and reproduction in any medium, provided the original work is properly cited. 


\section{INTRODUCTION}

Historical changes in land use have cost the Brazilian savanna biome dearly. Currently the Cerrado, considered a complex mosaic of vegetation types (Bueno et al., 2018) is a fragmented biome composed of underutilized areas that exposes the soil to irreversible degradation processes (Hunke et al., 2015a; Anache et al., 2018). Due to the history of severe changes, the recovery of these areas becomes essential. However, how to do this on an acid soil with naturally low fertility?

Since the beginning of the 20th century, Eucalyptus plantations, which originally were to meet woos demand of the Companhia Paulista de Estrada de Ferro, are the main source of timber in the country. Nowadays they occupy an area of 6.97 million hectares (Indústria Brasileira de Árvores, 2020), while this woody tree genus has been genetically improved allowing its establishment on many site conditions.

However, due to the inherent environmental impacts of a monoculture, Eucalyptus became the subject of discussion and controversy (Farinaci et al., 2013). Nevertheless, scientific studies attest the ability of stands to provide benefits to the soil; e.g. nutrient mineralization and increased water retention capacity (Gatto et al., 2014; Suzuki et al., 2014; Assis et al., 2015).

These positive factors are linked to the litterfall and its respectively decomposition. In this sense, the manipulation, i.e., the removal or addition of plant residues attests the effect of this organic component on the soil nutrient availability and soil respiration of the Cerrado (Villalobos-Vega et al., 2011). The management of residues in Eucalyptus stands also positively affects the commercial plantations' productivity (Mendham et al., 2014).

In order to verify the litterfall ability to promote soil benefits in Eucalyptus stand, this study aimed to show the impacts of litter layer removal on litterfall, leaf decomposition and physicochemical properties in a Eucalyptus stand growing on Cerrado dystrophic soil conditions. It was hypothesized that removal of litter layer would decrease the leaf decomposition rate and alter the physical and chemical soil characteristics.

\section{MATERIAL AND METHODS}

\section{Study area}

The Eucalyptus stand is located at Fazenda Água Limpa (Figure 1), which belongs to the Universidade de Brasília, situated at the Distrito Federal, Brazil (15 $56^{\prime}-15$ 59' S and $47^{\circ} 55^{\prime}-4758^{\prime}$ WGr.). The farm has 4,340 ha of total area, about 2,340 ha of which were intended for preservation, while 1,200 ha were for academic studies focused on wood production, livestock and agriculture.

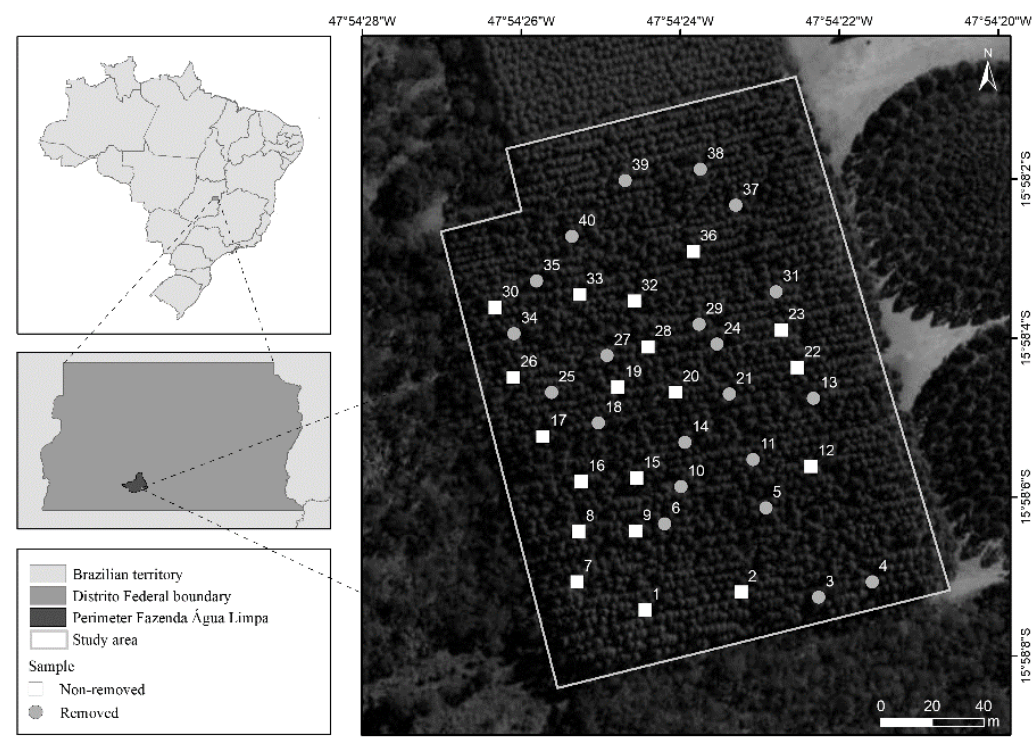

Figure 1. Eucalyptus stand and experimental plots at Fazenda Água Limpa, Distrito Federal, Brazil. 
The weather in the region is described by Köppen as Aw, with maximum and minimum temperatures of $28.5^{\circ} \mathrm{C}$ and $12.0^{\circ} \mathrm{C}$, respectively (Alvares et al., 2014). During the collection period, from November 2016 to October 2017, the average temperature was $21.03^{\circ} \mathrm{C}$; and total precipitation was $907.00 \mathrm{~mm}$; both parameters were obtained by the Fazenda Água Limpa automatic climatological station (Figure 2). Soils in the stand area are described as Latossolo Vermelho distrófico (Empresa Brasileira de Pesquisa Agropecuária, 2018) (Red Oxisol). The dystrophic classification was considered by the low base saturation $(\mathrm{V}<50 \%)$ and the high level of aluminum saturation (m) (Sousa \& Lobato, 2004).

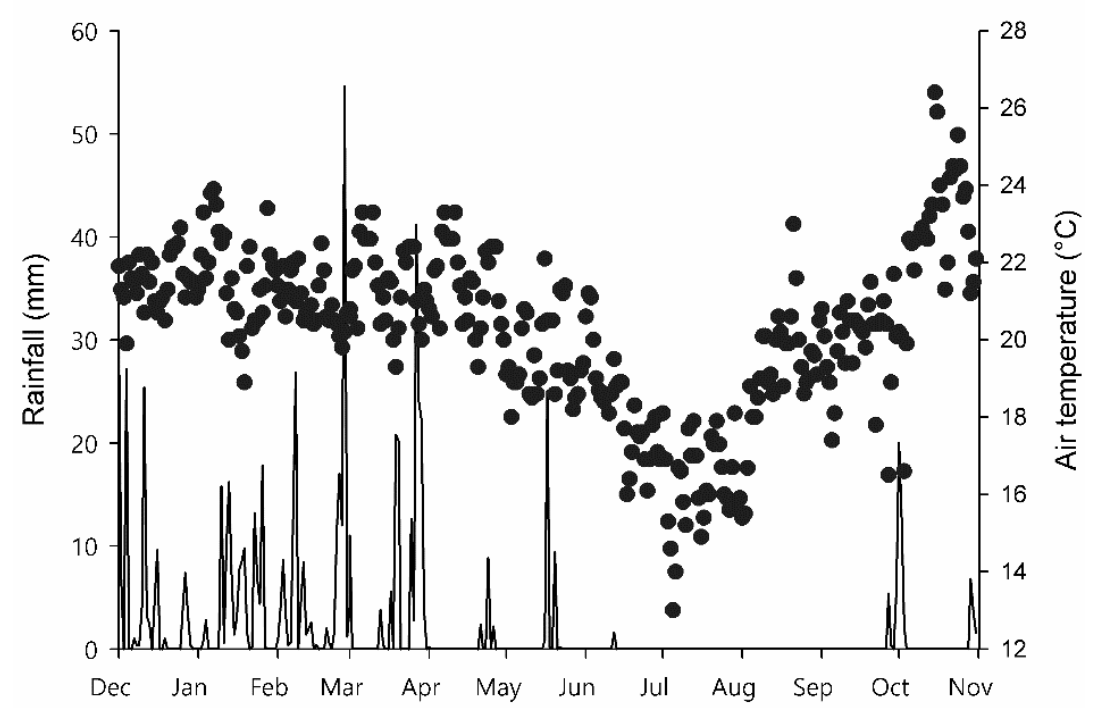

Figure 2. Rainfall (mm) and air temperature $\left({ }^{\circ} \mathrm{C}\right)$ from December 2016 to November 2017 at Fazenda Água Limpa, Universidade de Brasília, Distrito Federal, Brazil.

The Eucalyptus stand was established in January 2010 (72 months), with a total area of 3.29 hectares. The planting of 1224 clone Eucalyptus urophylla S. T. Blake x Eucalyptus grandis Hill ex-Maiden was performed in $3 \mathrm{~m} \times 2 \mathrm{~m}$ spacing. Soil preparation was done by plowing down to $40 \mathrm{~cm}$ depth. Fertilization was done along the planting line by application of $100 \mathrm{~g}$ of super simple phosphate $+100 \mathrm{~g}$ of NPK (4-30-16); liming was not performed previously.

The $10 \mathrm{~m} \times 10 \mathrm{~m}$ plots were randomly allocated, being twenty plots of non-removed litter layer and another twenty of removed litter layer (Figure 1). The litter layer was removed every two months during the experiment. By harvesting and weighing of 40 trees, the modeling of volume and biomass for the stand was undertaken using Schumacher-Hall model (Schumacher \& Hall, 1933) to estimate the volume and biomass for each of previously inventoried trees in the study area. The mean volume was $328.88 \mathrm{~m}^{3} \mathrm{ha}^{-1}$ and $181.405 \mathrm{Mg} \mathrm{ha}^{-1}$ for biomass (Valadão et al., 2020). The soil sampling for determination of physical parameters was done in January, March, May, July, September and November in 2017. Soil samples for chemical analysis were collected in August 2017 during the dry period.

\section{Litterfall}

Forty litterfall traps, with $0.25 \mathrm{~m}^{2}$ area were distributed along the centerline of each plot to quantify litterfall. The area sampled was within the recommended limit for litterfall samplings, which considers a minimum of eight litterfall traps per hectare (Finotti et al., 2003).

From December 2016 to November 2017 monthly collections were performed. Samples were separated into fractions of: leaves, reproductive parts, branches and miscellaneous. Litterfall was quantified by means of constant dry weight after oven drying at $65^{\circ} \mathrm{C}$ and weighing of the fractions on a precision scale and calculated in $\mathrm{Mg} \mathrm{ha}^{-1}$. 


\section{Leaf decomposition and chemical attributes}

The leaves decomposition rate was verified by the confinement of freshly fallen leaves into litter bags $(20 \times 20 \mathrm{~cm})$ made of $2 \mathrm{~mm}$ nylon mesh. Each litter bag was filled with $20.00 \mathrm{~g}$ of leaf material and placed on the ground in each of the 40 plots for monthly collection during the year of study.

Leaf decay was calculated as a function of mean biomass losses over time with the following equation: remaining mass $(\%)=($ final mass/initial mass) $\times 100$. The constant $k$, calculated monthly (12 periods), was obtained by the simple exponential equation proposed by Olson (1963): $X_{t}=X_{0} \cdot e^{-k t}$, where $X_{t}=$ dry weight of material remaining after $t$ days and $X_{0}=$ dry weight of material at $\mathrm{t}=0$ ). Half-life time was calculated by means of the equation $t^{\frac{1}{2}}=\ln (2) / k$ (Olson, 1963).

The $\mathrm{P}, \mathrm{K}, \mathrm{Ca}$ and $\mathrm{Mg}$ concentration in the leaves were determined by nitro-perchloric digestion and analysis by Inductive Coupling Plasma. Sulfuric digestion and distillation were used for $\mathrm{N}$ concentration by the Kjeldahl method.

\section{Soil physics and fertility}

Soil chemical properties samples were performed to evaluate its acidity and fertility intrinsic characteristics. In all lots, six combined soil cores samples at a 0-20, 20-40 and 40$60 \mathrm{~cm}$ of depth were collected and analyzed. The soil was collected in August 2017 during the dry season.

The soil acidy was determined by the concentration of $\mathrm{pH}$ by distilled water method; exchangeable aluminum $\left(\mathrm{Al}^{3+}\right)$, potential acidity $(\mathrm{H}+\mathrm{Al})$ by titration. Phosphorus $(\mathrm{P})$ and potassium $(\mathrm{K})$ by Mehlich $^{-1}$ extractor, $\mathrm{P}$ was determined using molecular absorption spectrophotometer and $\mathrm{K}$ by photometer of flame; calcium $\left(\mathrm{Ca}^{2+}\right)$, magnesium $\left(\mathrm{Mg}^{2+}\right)$ were measured by atomic absorption spectrophotometer; organic matter (OM) by extraction and titration. By the results it was possible to calculate the total cation exchange capacity $\left(\mathrm{CEC}_{\mathrm{T}}\right)$, effective cation exchange capacity $\left(C E C_{t}\right)$, sum of bases $(S B)$, base saturation $(V)$ and saturation by aluminum (m).

The density and the volumetric humidity were evaluated by the volumetric ring method, according to Claessen (1997) at 0-20, 20-40 and 40-60 cm depth. These physical soil properties were evaluated in January, March, May, July, September and November in 2017.

\section{Data analysis}

The litterfall, leaf decomposition and physico-chemical soil properties were compared by analysis of variance. The comparison between non-removed and removed litter layer plots was made by the independent t-test.

Tukey's test was made a posteriori to identify significant differences between means. Normality and homogeneity of variances were verified by the Shapiro-Wilk and Levene tests, respectively. When these assumptions were not met, the Kruskal Wallis non-parametric test was used. Analyses were carried out using the PAST program 2.15 (Hammer et al., 2001).

\section{RESULTS AND DISCUSSION}

\section{Litterfall}

No differences were found in litterfall when comparing non-litter removed and litter removed plots. During October, for both treatments, higher litterfall was observed; however, there was no distinction from May, June, July, August and September in both treatments. On the order hand, December was the one with the lowest production in both plots. The total litterfall was 7.33 and $7.50 \mathrm{Mg} \mathrm{ha}^{-1}$ respectively in non-litter removed and litter removed plots.

The contribution for each litterfall fraction to litter layer showed that leaves were the main attribute contributing to the litter layer formation except in November, when miscellaneous 
had contributed more (Figure 3). Non-litter removed and litter removed plots have showed similar litterfall pattern.

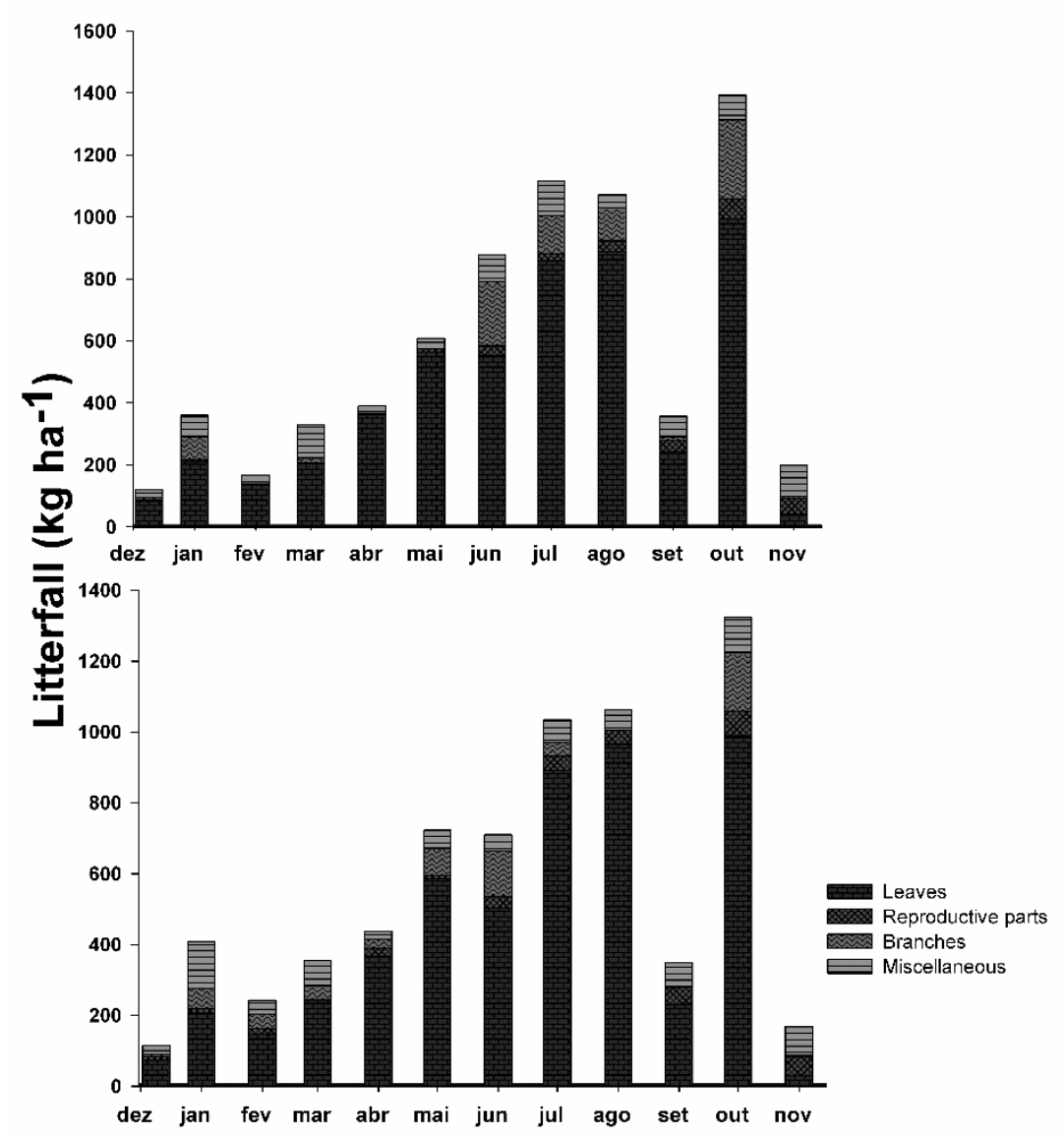

Figure 3. Litterfall fractions $\left(\mathrm{kg} \mathrm{ha}^{-1}\right)$ during twelve months in Eucalyptus stand with non-litter removed (A) and litter removed (B) at Fazenda Água Limpa, Distrito Federal, Brazil.

The studied stand presented higher litterfall production than stands with different age in Brazilian biomes (e.g. in Pampa biome) with 16.5 months (Corrêa et al., 2013) and Eucalyptus stand previously occupied by Atlantic forest in Rio de Janeiro at 24 months (Melos et al., 2010). Probably the higher deposition of litter was influenced mainly by the seasonality of the Cerrado, where trees may lose part of the leaves due to the low water availability during the driest period.

The total litter observed in this experiment was higher when compared with a stand located in similar edaphoclimatic conditions, planting spacing and age (Vieira et al., 2009). This distinction could be attributed to the different microclimatic conditions, fertilization of planting and quality of the planted seedlings.

This pattern of high litterfall is related to the age of the stand (Schumacher et al., 2013), and the canopy closure with reduction of the luminosity that favors the natural pruning. These conditions reflect high litter layer (e.g. in stands established in low fertility in the Cerrado biome) (Ribeiro et al., 2017; Valadão et al., 2019).

The litter layer removal did not affect litterfall during one year. However, older stands are more dependent to the organic material deposited on the soil by litterfall (Schumacher \& Viera, 2015). The indistinct pattern between non-litter removed and litter removed plots may be related to the short time of litter layer removal. In Cerrado stricto sensu Villalobos-Vega et al. (2011) reported changes in the litterfall pattern in plots submitted to litter layer manipulation only in the second year. 


\section{Leaf decomposition}

The leaf biomass decay showed a distinct pattern when comparing non-removed and removed litter layer plots. In general, the material degradation was more constant in non-litter removed than in litter removed plots; this pattern is better illustrated by the exponential regression (Figure 4).

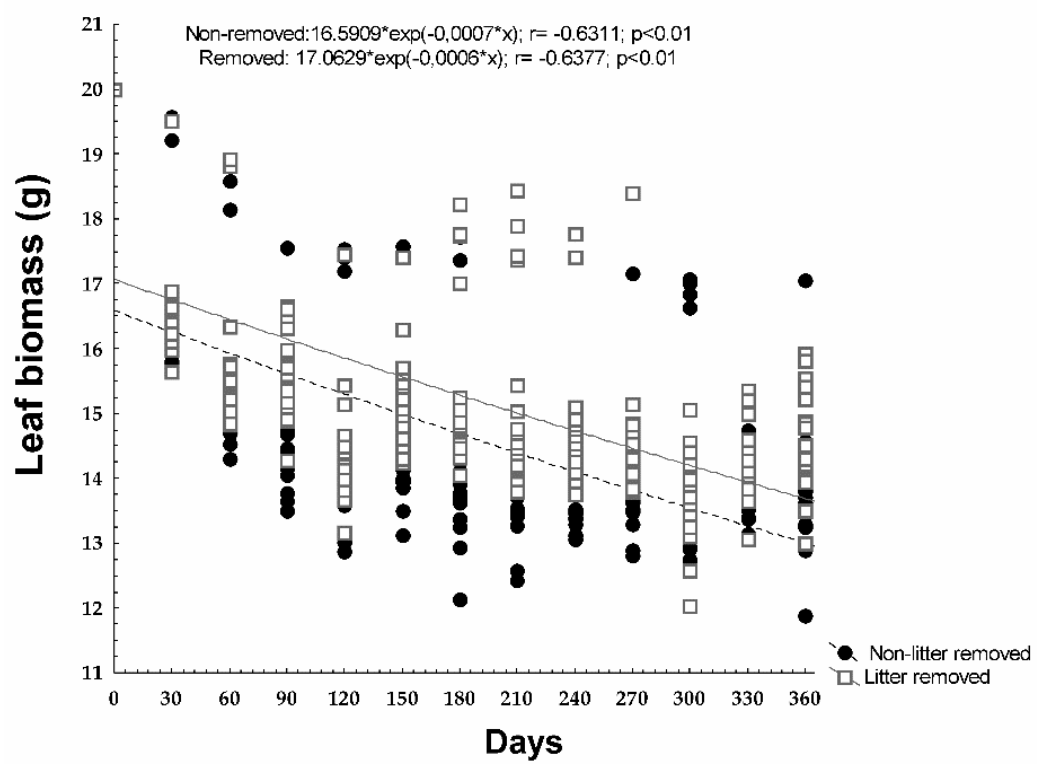

Figure 4. Exponential regression of leaf biomass decay (g) during one year in non-litter removed litter layer plots in Eucalyptus stand at Fazenda Água Limpa, Distrito Federal, Brazil.

The constant $k$, obtained by the exponential regression also reinforced the distinction between litter removed plot treatments. For the non-litter removed plots the $k$ constant was 0.0007 while in the litter removed, it was 0.0006 . Although they may seem as approximate values, this difference represented the delay of almost one-half of a year in relation to the half-life $\left(T^{1 / 2}\right)$, which represents 990 and 1,155 days respectively in non-litter removed and litter removed plots. The comparison between the days after the beginning of the experiment presented differences. In nine periods the mean of leaf biomass was greater in non-litter removed than litter removed plots (Table 1).

Table 1. Remaining leaf biomass weight ( $\mathrm{g}$ ) and percentage (\%) during one year in non-litter removed and litter removed plots in a Eucalyptus stand, at Fazenda Água Limpa, Distrito Federal, Brazil.

\begin{tabular}{ccc}
\hline \multirow{2}{*}{$\begin{array}{c}\text { Days after the beginning } \\
\text { of the experiment }\end{array}$} & \multicolumn{2}{c}{ Remaining leaf biomass $(\mathbf{g})$} \\
\cline { 2 - 3 } & Non-litter removed & Litter removed \\
\hline 0 & $20.00(100 \%) \mathrm{a}$ & $20.00(100 \%) \mathrm{a}$ \\
60 & $16.40(82 \%) \mathrm{a}$ & $16.55(83 \%) \mathrm{a}$ \\
90 & $15.28(76 \%) \mathrm{a}$ & $15.71(78 \%) \mathrm{a}$ \\
120 & $14.58(73 \%) \mathrm{a}$ & $15.49(77 \%) \mathrm{b}$ \\
150 & $14.61(73 \%) \mathrm{a}$ & $14.56(73 \%) \mathrm{a}$ \\
180 & $14.34(72 \%) \mathrm{a}$ & $15.16(76 \%) \mathrm{b}$ \\
210 & $14.10(70 \%) \mathrm{a}$ & $15.35(76 \%) \mathrm{b}$ \\
240 & $13.61(68 \%) \mathrm{a}$ & $15.12(75 \%) \mathrm{b}$ \\
270 & $13.73(68 \%) \mathrm{a}$ & $14.69(73 \%) \mathrm{b}$ \\
300 & $13.87(69 \%) \mathrm{a}$ & $14.64(73 \%) \mathrm{b}$ \\
330 & $13.77(68 \%) \mathrm{a}$ & $14.21(71 \%) \mathrm{b}$ \\
360 & $13.76(68 \%) \mathrm{a}$ & $14.21(71 \%) \mathrm{b}$ \\
\hline
\end{tabular}

Means followed by the same lowercase letter on the line do not differ, according to Tukey test at $5 \%$ of probability. 
The leaf decomposition trend was changed as a result of the litter layer removal only in one year. Removal of litter layer results in substantial changes in Cerrado soils, as asserted by Villalobos-Vega et al. (2011); it implies changes in maximum soil temperature, water content and soil respiration. These variations may affect the heterotrophic and autotrophic respirations and the litter decomposition which are responsible for $41 \%$ of the total $\mathrm{CO}_{2}$ efflux from the soil (Versini et al., 2013).

Eucalyptus leaves are rich in tannin and polyphenols (Santos et al., 2018). In general, even after three months during which the leaves are deposited on the soil, structural constituents, for example lignin, still remains, reducing decomposition rates (Carvalho et al., 2009; Viera et al., 2014; Lima et al., 2015).

As for nutrients, the decomposition process showed an increase in the nitrogen content at 360 days in both treatments comparing to the zero time. In no-removed plots, in addition to nitrogen, calcium also had higher mean concentrations compared to time zero (Table 2). The levels of $\mathrm{K}, \mathrm{Mg}$ and $\mathrm{C}$ decreased in both treatments, but there was no statistical difference for the concentration of $\mathrm{Ca}$ in removed plots (Table 2). At the end of one year, the concentrations of $\mathrm{K}, \mathrm{Ca}, \mathrm{Mg}$ and $\mathrm{C}$ were lower in the leaves deposited on the soil of the removed plots comparing both treatments (Table 2 ).

Table 2. Chemical characteristics of leaves at day 0 and day 360 days in non-litter removed and litter removed plots in Eucalyptus stand, at Fazenda Água Limpa, Distrito Federal, Brazil.

\begin{tabular}{|c|c|c|c|c|c|c|}
\hline \multirow{2}{*}{ Non-litter removed Plots } & $\mathbf{N}$ & $\mathbf{P}$ & $\mathbf{K}$ & $\mathrm{Ca}$ & Mg & C \\
\hline & \multicolumn{6}{|c|}{ - } \\
\hline Day - 0 & $0.64 a$ & $0.03 a$ & $0.22 a$ & $0.61 a$ & $0.34 a$ & $56.45 a$ \\
\hline Day - 360 - non-litter removed & $0.82 b$ & $0.03 a$ & $0.07 \mathrm{~b}$ & $0.70 b$ & $0.25 b$ & $55.69 b$ \\
\hline Litter removed Plots & \multicolumn{6}{|c|}{ 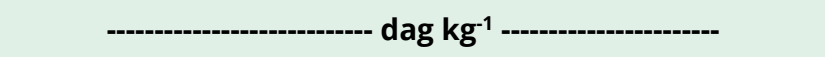 } \\
\hline Day - 0 & $0.64 a$ & $0.03 a$ & $0.22 a$ & $0.61 a$ & $0.34 a$ & $56.45 a$ \\
\hline \multirow[t]{2}{*}{ Day - 360 - litter removed } & $0.79 b$ & $0.03 a$ & $0.06 b$ & $0.63 a$ & $0.20 \mathrm{~b}$ & $53.68 b$ \\
\hline & \multicolumn{6}{|c|}{ 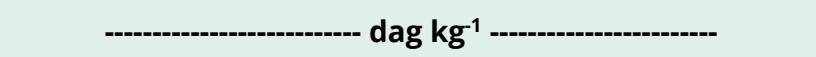 } \\
\hline Day - 360 - non-litter removed plots & $0.82 a$ & $0.03 a$ & $0.07 a$ & $0.70 a$ & $0.25 a$ & $55.69 a$ \\
\hline Day - 360 - litter removed plots & $0.79 a$ & $0.03 a$ & $0.06 b$ & $0.63 b$ & $0.20 \mathrm{~b}$ & $53.66 b$ \\
\hline
\end{tabular}

Means followed by the same lowercase letter on the column do not differ, according to Tukey test at $5 \%$ of probability. Médias seguidas pela mesma letra minúscula na coluna não diferem de acordo com o teste de Tukey a $5 \%$ de probabilidade.

The sequence of decreasing concentration of nutrients was $\mathrm{N}>\mathrm{Ca}>\mathrm{Mg}>\mathrm{K}>\mathrm{P}$ in newly fallen leaves (day 0); in non-litter removed and litter removed plots (day 360). There was an increment of $\mathrm{N}$ and $\mathrm{Ca}$ concentration from the beginning to the end of the experiment. The litterfall leaves act as a sink for $\mathrm{N}$ and $\mathrm{P}$ macronutrients in Eucalyptus stands (Momolli et al., 2018). During the initial period of decomposition there is a carbon metabolization and $N$ immobilization by microorganisms (Rawat \& Singh, 1995). The amount of lignin increases during half of the first year in Eucalyptus leaves (Costa et al., 2005); the relationship between $\mathrm{N}$ concentration and changes in absolute amount of carbon indicates that the higher initial amount of lignin results in a greater amount of nitrogen immobilized per unit of carbon respired (Melillo et al., 1982).

In leaves, calcium has low mobility and a large amount of $\mathrm{Ca}$ is located in the cell wall (Lima et al., 2018). During the decomposition process of the Eucalyptus leaves the release of $\mathrm{Ca}$ is low, after 36 months $80 \%$ of this macronutrient still present in the leaves (Viera et al., 2014).

Potassium showed the greatest decrease between the beginning and the end of the experiment in non-litter removed and litter removed plots. This decrease, was also verified by 
Carvalho et al. (2017) in a Eucalyptus stand, and it is justified by the fact that K, even not participating in the structure of the plant tissue, it is easily leached by water that percolates through the soil profile (Dutta \& Agrawal, 2001; Vilela et al., 2004) and this macronutrient becomes readily mineralized (Momolli et al., 2018). Still, comparing Eucalyptus stand with a native and regeneration forest; $\mathrm{K}$ leach is slower (Carvalho et al., 2017).

\section{Fertility and physics of soil}

Soil Chemical analyses (Table 3) revealed a low base saturation $(\mathrm{V}<50 \%)$ and high aluminum saturation (m); classifying this soil as dystrophic (Sousa \& Lobato, 2004); being the most common soil type in the Brazilian Cerrado. The texture was considered very clayey and according Sousa \& Lobato (2004) the levels of $\mathrm{P}, \mathrm{K} \mathrm{Ca}^{2+}, \mathrm{Mg}^{2+}, \mathrm{CEC}_{\mathrm{t}}, \mathrm{CEC}_{\mathrm{T}}, \mathrm{SB}$ and OM at 0$20 \mathrm{~cm}$ depth are considered low.

Potassium and base saturation were different comparing different treatments. The concentration of $\mathrm{K}$ was different in the three depths in non-litter removed plots, however, in litter removed plots 20-40 and 40-60 cm there was no statistic difference (Table 3). Base saturation did not differ in non-litter removed plots (Table 3), however, in litter removed plots, the mean at 0-20 cm was higher than at 20-40 and 40-60 cm (Table 3). Other chemical attributes (e.g. $\mathrm{pH}, \mathrm{OM}, \mathrm{P}, \mathrm{Mg}^{2+}, \mathrm{Al}^{3+}, \mathrm{H}+\mathrm{Al}, \mathrm{CEC}, \mathrm{CEC}$, $\mathrm{SB}$ and $\mathrm{m}$ ) were similar in both treatments with larger mean values in the depth of 0-20 cm (Table 3 ).

Table 3. Chemical attributes of a dystrophic Red Latosol (Oxisol) under a Eucalyptus stand in non-litter removed and litter removed plots at Fazenda Água Limpa, Distrito Federal, Brazil.

\begin{tabular}{|c|c|c|c|c|c|c|c|c|c|c|c|c|c|}
\hline Depth (cm) & pH & OM & $\mathbf{P}$ & K & $\mathrm{Ca}^{2+}$ & $\mathrm{Mg}^{2+}$ & $\mathrm{Al}^{3+}$ & $\mathrm{H}+\mathrm{Al}$ & CEC $_{t}$ & $\mathrm{CEC}_{\mathrm{T}}$ & SB & v & m \\
\hline $\begin{array}{l}\text { Non-litter } \\
\text { removed }\end{array}$ & $\mathrm{H}_{2} \mathrm{O}$ & dag kg $^{-1}$ & $-m g d$ & $\mathrm{Im}^{-3}$ & & 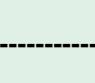 & $--c$ & $\mathrm{dm}$ & 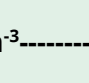 & & & -----o, & $\%$ \\
\hline $0-20$ & $4.9 \mathrm{~b}$ & $4.5 a$ & $0.35 b$ & $13.5 a$ & $0.03 a$ & $0.12 b$ & $0.41 b$ & $7.4 a$ & $0.59 b$ & $7.55 a$ & $0.18 b$ & $2.35 a$ & $69.73 b$ \\
\hline $20-40$ & $5.2 \mathrm{a}$ & $3.1 b$ & $0.15 a$ & $4.2 b$ & $0.02 a$ & $0.06 a$ & $0.01 a$ & $4.4 \mathrm{~b}$ & $0.10 a$ & $4.53 b$ & $0.10 a$ & $2.06 a$ & $0.01 a$ \\
\hline $40-60$ & $5.1 a$ & $2.6 c$ & $0.01 a$ & $1.8 \mathrm{c}$ & $0.02 a$ & $0.05 a$ & $0.01 a$ & $3.7 c$ & $0.07 a$ & $3.74 \mathrm{c}$ & $0.07 a$ & $1.97 a$ & $0.01 a$ \\
\hline $\begin{array}{l}\text { Litter } \\
\text { removed }\end{array}$ & $\mathrm{H}_{2} \mathrm{O}$ & dag kg $^{-1}$ & $-m g d$ & $\mathrm{Im}^{-3}$ & & 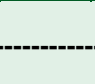 & $-c$ & $\mathrm{co}^{\circ}$ & 3 & & ----. & 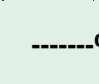 & -\%----- \\
\hline $0-20$ & $4.9 \mathrm{k}$ & $4.3 a$ & $0.68 b$ & $14.0 \mathrm{~b}$ & $0.03 a$ & $0.11 b$ & $0.44 b$ & $7.3 a$ & $0.62 b$ & $7.43 a$ & $0.18 b$ & $2.37 \mathrm{~b}$ & $70.62 b$ \\
\hline $20-40$ & $5.1 a$ & $2.9 \mathrm{~b}$ & $0.13 a$ & $4.0 a$ & $0.01 a$ & $0.04 a$ & $0.01 a$ & $4.4 b$ & $0.05 a$ & $4.44 b$ & $0.05 a$ & $1.20 a$ & $0.01 a$ \\
\hline $40-60$ & $5.0 a$ & $2.4 \mathrm{c}$ & $0.20 a$ & $2.3 a$ & $0.01 a$ & $0.03 a$ & $0.01 a$ & $3.7 c$ & $0.04 a$ & $3.69 c$ & $0.04 a$ & $1.18 a$ & $0.01 a$ \\
\hline
\end{tabular}

Means followed by the same lowercase letter on the column do not differ, according to Tukey test at $5 \%$ of probability. Médias seguidas pela mesma letra minúscula na coluna não diferem de acordo com o teste de Tukey a $5 \%$ de probabilidade.

Even with low natural fertility, the Oxisol have high agricultural potential; this viability was essential for the establishment of Eucalyptus stand on Cerrado. In the latter 70's and early 80's Novais et al. (1979) and Neves et al. (1982) reported in under nursery and field conditions the tolerance of Eucalyptus to acid soils, and proposing liming in order to raise levels of calcium and magnesium (Barros et al., 2014).

The distinctions observed in chemical attributes are the results from soil genesis processes. Cantarutti et al. (2007) argue that cultural practices, such as localized fertilization, and the root system of cultivated plants accentuate this variability among the different layers of the soil. The distinction of the mean concentrations of $\mathrm{K}$ and consequently $\mathrm{V}$ may be a reflection of the litter removal alteration in the vertical soil profile. (Table 4).

Potassium has a great soil mobility (Ernani et al., 2007); the removal of the litter layer facilitated water penetration and the percolation of this macronutrient to lower layers of soil. This distinction for potassium was not observed in sandy soil that received an increase of 
organic material coming from the Eucalyptus harvest in the Congo (Versini et al., 2014). However, the amount of clay in Cerrado Latosol (Oxisol) can reduce the percolation of mobility elements in the soil.

The change of land use in Cerrado Latosol (Oxisol) causes a decrease in potassium concentration (e.g. sugarcane crop) (Hunke et al., 2015b). However, in a Crop-Livestock-Forest Integration system (CLFI) when Eucalyptus is the forest component, there is no difference to the original Cerrado as for $\mathrm{K}$ concentration (Ramos et al., 2018).

However, the Eucalyptus harvest residue was not able to increase the concentration of potassium in an 8-year cut cycle Eucalyptus stand, established in a Cerrado Oxisol (Rocha et al., 2016). The increment of organic material was not able to result in significant changes in the fertility of this dystrophic soil, thus an increment by mineral fertilization is recommended.

The soil moisture at the depth interval $40-60 \mathrm{~cm}$ was higher in the litter removed plots in January. Also, in March, during the rainy season, there was a difference between depth interval 0-20 and 40-60 cm, only on non-litter removed (Table 4). In May, which was preceded by 12 days without rain, the non-litter removed plots presented higher moisture at the $0-20 \mathrm{~cm}$ soil depth interval. In September, soil moisture was lower in the 0-20 cm compared to the 20-40 and 40-60 intervals only in the litter removed plots (Table 4).

The density in the litter removed plots at $40-60 \mathrm{~cm}$ was compared to $0-20 \mathrm{~cm}$ depth interval in September; this month was preceded by 91 days without rain (Figure 2). In nonlitter removed plots, the density of the $0-20 \mathrm{~cm}$ interval was the lowest in November, after occurrence of precipitation. The porosity parameter was similar to the density, with the exception of January, when the average was higher in non-litter removed (Table 4).

Table 4. Physical soil parameters in non-litter removed and litter removed plots during 2017 in a Eucalyptus stand, at Fazenda Água Limpa, Distrito Federal, Brazil.

\begin{tabular}{|c|c|c|c|c|c|c|c|}
\hline \multirow{3}{*}{ Month } & & \multicolumn{2}{|c|}{ Moisture $\left(\mathrm{m}^{3} \mathrm{~m}^{-3}\right)$} & \multicolumn{2}{|c|}{ Density $\left(\mathrm{kg} \mathrm{dm}^{-3}\right)$} & \multicolumn{2}{|c|}{ Total porosity $\left(\mathrm{m}^{3} \mathrm{~m}^{-3}\right)$} \\
\hline & & $\begin{array}{l}\text { Non-litter } \\
\text { removed }\end{array}$ & $\begin{array}{c}\text { Litter } \\
\text { removed }\end{array}$ & $\begin{array}{l}\text { Non-litter } \\
\text { removed }\end{array}$ & $\begin{array}{l}\text { Litter } \\
\text { removed }\end{array}$ & $\begin{array}{l}\text { Non-litter } \\
\text { removed }\end{array}$ & $\begin{array}{l}\text { Litter } \\
\text { removed }\end{array}$ \\
\hline & \multicolumn{7}{|l|}{$\overline{\text { Depth (cm) }}$} \\
\hline \multirow{4}{*}{ Jan } & $0-20$ & $29.52 \mathrm{aA}$ & $30.90 \mathrm{aA}$ & $0.94 a A$ & $0.95 \mathrm{aA}$ & $64.17 \mathrm{aA}$ & $63.94 \mathrm{aA}$ \\
\hline & $20-40$ & $26.88 \mathrm{aA}$ & $28.45 \mathrm{aA}$ & $0.94 \mathrm{aA}$ & $0.96 \mathrm{aA}$ & $64.52 \mathrm{aA}$ & $63.46 \mathrm{aA}$ \\
\hline & $40-60$ & $24.46 \mathrm{aA}$ & $27.59 \mathrm{bA}$ & $0.96 \mathrm{aA}$ & $0.95 \mathrm{aA}$ & $66.47 a A$ & $63.84 \mathrm{bA}$ \\
\hline & $0-20$ & $27.34 a B$ & $28.05 \mathrm{aA}$ & $0.91 \mathrm{aA}$ & $0.89 \mathrm{aA}$ & $65.62 \mathrm{aA}$ & $66.35 a A$ \\
\hline \multirow[t]{3}{*}{ Mar } & $20-40$ & $30.28 a A B$ & $30.36 \mathrm{aA}$ & $0.94 a A$ & $0.99 a A$ & $66.88 \mathrm{aA}$ & $62.37 a A$ \\
\hline & $40-60$ & $31.58 \mathrm{aA}$ & $30.80 \mathrm{aA}$ & $0.96 a A$ & $0.92 \mathrm{aA}$ & $63.43 a \mathrm{~A}$ & $64.97 a A$ \\
\hline & $0-20$ & $25.21 \mathrm{aA}$ & $22.59 \mathrm{bA}$ & $0.94 a A$ & $0.89 a \mathrm{~A}$ & $64.25 \mathrm{aA}$ & $67.50 \mathrm{aA}$ \\
\hline \multirow[t]{3}{*}{ May } & $20-40$ & $24.49 a \mathrm{~A}$ & $23.66 \mathrm{aA}$ & $0.93 a A$ & $0.90 \mathrm{aA}$ & $64.77 a A$ & $65.96 \mathrm{aA}$ \\
\hline & $40-60$ & $24.28 \mathrm{aA}$ & $23.42 \mathrm{aA}$ & $0.91 \mathrm{aA}$ & $0.88 \mathrm{aA}$ & $65.33 a A$ & $66.66 \mathrm{aA}$ \\
\hline & $0-20$ & $25.21 \mathrm{aA}$ & $22.49 \mathrm{aA}$ & $0.88 \mathrm{aA}$ & $0.90 \mathrm{aA}$ & $66.61 \mathrm{aA}$ & $65.94 \mathrm{aA}$ \\
\hline \multirow[t]{3}{*}{ Jul } & $20-40$ & $22.59 a A$ & $22.75 \mathrm{aA}$ & $0.87 a A$ & $0.89 \mathrm{aA}$ & $66.88 \mathrm{aA}$ & $66.22 \mathrm{aA}$ \\
\hline & $40-60$ & $23.61 \mathrm{aA}$ & $22.90 \mathrm{aA}$ & $0.90 \mathrm{aA}$ & $0.89 \mathrm{aA}$ & $65.68 \mathrm{aA}$ & $66.41 \mathrm{aA}$ \\
\hline & $0-20$ & 23.19aA & $21.02 \mathrm{aB}$ & $0.97 a A$ & $0.89 a \mathrm{~B}$ & $63.05 \mathrm{aA}$ & $66.30 \mathrm{aB}$ \\
\hline \multirow[t]{3}{*}{ Sep } & $20-40$ & $23.82 \mathrm{aA}$ & $23.98 \mathrm{aA}$ & $0.94 \mathrm{aA}$ & $0.95 \mathrm{aAB}$ & $64.46 \mathrm{aA}$ & $63.89 \mathrm{aAB}$ \\
\hline & $40-60$ & 23.98aA & $25.62 \mathrm{aA}$ & $0.93 a A$ & $0.99 \mathrm{aA}$ & 64.69aA & $62.38 \mathrm{aA}$ \\
\hline & $0-20$ & $31.95 \mathrm{aA}$ & $32.17 \mathrm{aA}$ & $0.84 \mathrm{aA}$ & $0.86 \mathrm{aA}$ & $68.16 \mathrm{aA}$ & $67.42 \mathrm{aA}$ \\
\hline \multirow[t]{2}{*}{ Nov } & $20-40$ & $36.89 a A$ & $36.87 \mathrm{aA}$ & $1.00 a \mathrm{~B}$ & $0.97 a A$ & $62.16 \mathrm{aB}$ & $63.38 \mathrm{aA}$ \\
\hline & $40-60$ & $34.26 \mathrm{aA}$ & $37.01 \mathrm{aA}$ & $0.91 \mathrm{aAB}$ & $0.94 \mathrm{aA}$ & $65.63 \mathrm{aAB}$ & $64.23 \mathrm{aA}$ \\
\hline
\end{tabular}

Means followed by the same lowercase letter in the row and uppercase in column do not differ. Médias seguidas pela mesma letra minúscula na linha e maiúscula na coluna não diferem de acordo com o teste de Tukey a $5 \%$ de probabilidade.

Contrasting with the low levels of macronutrients according to the chemical analysis, the amount of organic matter was considered satisfactory (Sousa \& Lobato, 2004) in both 
treatments (Table 4). However this input does not bring an upgrade in the soil fauna diversity (e.g. arthropod fauna) in the Eucalyptus monoculture (Tacca et al., 2017).

Moisture, density and total porosity, presented differences between non-litter removed and litter removed plots. In the case of moisture, Villalobos-Vega et al., (2011) also found distinctions in water content at the peak of the dry period (e.g. September) at the height of the dry season, in plots where litter layer was removed in Cerrado stricto sensu natural vegetation, also in the Federal District. The maintenance or the transport of the plant residue could protect exposed areas, ensuring ecosystem functions.

The improvement in the soil physical quality was also verified in Crop-Livestock-Forest Integration System (CLFIS) when the forest component was Eucalyptus. Assis et al., (2015) verified improvements in density and porosity parameters when comparing CLFIS with degraded pasture in Oxisol. The benefit of forest residues maintenance is also verified at the time of harvest, with reduction in soil compaction levels (Lopes et al., 2015). Versini et al. (2013), reinforce the idea that the management of organic residues from forest stands plays a crucial role in ensuring the sustainability of tropical soils with low natural fertility.

\section{CONCLUSION}

Litter layer removal changed the pattern of leaf decomposition, fertility and soil physics, confirming the tested hypothesis. Leaf decomposition was reduced in litter removed plots. The human interference on litter altered the potassium concentration in the vertical profile of the soil. Moisture also showed a difference in the wet and the dry period.

The maintenance of organic matter is a consensus in annual crops and commercial forest stands. The greater litterfall produced by Eucalyptus stands promotes the input of organic matter in dystrophic soils such as the Cerrado. The benefits are essential to attest to the feasibility of fast growing species such as Eucalyptus, which become a facilitating species in the recovery of a legal reserve, as was foreseen in the latest changes in the Brazilian forest code.

\section{ACKNOWLEDGMENTS}

The authors acknowledge the support from Fazenda Água Limpa, especially Sebastião Carlos Abadio, Geraldo Cardoso Oliveira, Augusto Pereira Alves, Mauro Barbosa dos Santos, Luiz Carlos Oliveira, Weiner Raulã Moreira Diniz, and Augusto Álvaro Pereira dos Santos.

\section{REFERENCES}

Alvares, C. A., Stape, J. L., Sentelhas, P. C., de Moraes Gonçalves, J. L., \& Sparovek, G. (2014). Köppen's climate classification map for Brazil. Meteorologische Zeitschrift (Berlin), 22(6), 711-728. http://dx.doi.org/10.1127/0941-2948/2013/0507.

Anache, J. A. A., Flanagan, D. C., Srivastava, A., \& Wendland, E. C. (2018). Land use and climate change impacts on runoff and soil erosion at the hillslope scale in the Brazilian Cerrado. The Science of the Total Environment, 622-623, 140-151. PMid:29212051. http://dx.doi.org/10.1016/j.scitotenv.2017.11.257.

Assis, P. C. R., Stone, L. F., Medeiros, J. C., Madari, B. E., Oliveira, J. M., \& Wruck, F. J. (2015). Atributos físicos do solo em sistemas de integração lavoura-pecuária-floresta. Revista Brasileira de Engenharia Agrícola e Ambiental, 19(4), 309-316. http://dx.doi.org/10.1590/1807-1929/agriambi.v19n4p309-316.

Barros, F. N., Neves, J. C. L., \& Novais, R. F. (2014). Nutrição e adubação mineral do eucalipto. In A. B. Vale, C. C. Machado, J. M. M. Pires, M. B. Vilar, C. B. Costa, \& P. A. Nacif. Eucaliptocultura no Brasil: silvicultura, manejo e ambiência (pp. 187-208). Viçosa: SIF.

Bueno, M. L., Dexter, K. G., Pennington, R. T., Pontara, V., Neves, D. M., Ratter, J. A., \& de Oliveira-Filho, A. T. (2018). The environmental triangle of the Cerrado Domain: ecological factors driving shifts in tree species composition between forests and savannas. Journal of Ecology, 106(5), 2109-2120. http://dx.doi.org/10.1111/1365-2745.12969.

Cantarutti, R. B., Barros, F. N., Martinez, H. E. P., \& Novais, R. F. (2007). Avaliação da fertilidade do solo e recomendação de fertilizantes. In R. F. Novais, V. H. A. Alvarez, N. F. Barros, R. L. F. F. Fontes, B. R. Antarutti \&J. C. L. Neves. Fertilidade do Solo (pp. 769-850). Viçosa: Sociedade Brasileira de Ciência do Solo. 
Carvalho, D. C., Pereira, M., Toledo, L. O., Simon, C. A., Rodrigues, J. D. S., Fernandes, J. C. F., \& Silva Neto, E. C. (2017). Ciclagem de nutrientes de um plantio de eucalipto em regeneração de espécies nativas no sub-bosque. Floresta, 47(1), 17-27. http://dx.doi.org/10.5380/rf.v47i1.43652.

Carvalho, W., Canilha, L., Ferraz, A., \& Milagres, A. M. F. (2009). Uma visão sobre a estrutura, composição e biodegradação da madeira. Quimica Nova, 32(8), 2191-2195. http://dx.doi.org/10.1590/S010040422009000800033.

Claessen, M. E. C. (1997). Manual de métodos de análise de solo (212 p.). Brasília: Embrapa-CNPS.

Corrêa, R. S., Schumacher, M. V., \& Momolli, D. R. (2013). Deposição de serapilheira e macronutrientes em povoamento de Eucalyptus dunnii Maiden sobre pastagem natural degradada no Bioma Pampa. Scientia Forestalis, 41, 65-74.

Costa, G. S., Gama-Rodrigues, A. C., \& Cunha, G. M. (2005). Decomposição e liberação de nutrientes da serapilheira foliar em povoamentos de Eucalyptus grandis no Norte Fluminense. Revista Árvore, 29(4), 563-570. http://dx.doi.org/10.1590/S0100-67622005000400008.

Dutta, R. K., \& Agrawal, M. (2001). Litterfall, litter decomposition and nutrient release in five exotic plant species planted on coal mine spoils. Pedobiologia, 45(4), 298-312. http://dx.doi.org/10.1078/00314056-00088.

Empresa Brasileira de Pesquisa Agropecuária - EMBRAPA. (2018). Sistema brasileiro de classificação de solos (356 p.). Brasília: EMBRAPA.

Ernani, P. R., Almeida, J., \& Santos, F. C. (2007). Potássio. In R. F. Novais, V. H. A. Alvarez, N. F. Barros, R. L. F. F. Fontes, B. R. Cantarutti \& J. C. L. Neves. Fertilidade do solo (pp. 551-594). Viçosa: Sociedade Brasileira de Ciência do Solo.

Farinaci, J. S., Ferreira, L. C., \& Batistella, M. (2013). Transição florestal e modernização ecológica: a eucaliptocultura para além do bem e do mal. Ambiente \& Sociedade, 16(2), 25-46. http://dx.doi.org/10.1590/S1414-753X2013000200003.

Finotti, R., Freitas, S. R., Cerqueira, R., \& Vieira, M. V. (2003). A method to determine the minimum number of litter traps in litterfall studies. Biotropica, 35(3), 419-421. http://dx.doi.org/10.1111/j.1744-7429.2003.tb00595.x.

Gatto, A., Bussinguer, A. P., Ribeiro, F. C., Azevedo, G. B., Bueno, C. B., Monteiro, M. M., \& Souza, P. F. (2014). Ciclagem e Balanço de Nutrientes no Sistema Solo-Planta em um Plantio de Eucalyptus sp., no Distrito Federal. Revista Brasileira de Ciência do Solo, 38(3), 879-887. http://dx.doi.org/10.1590/S0100-06832014000300019.

Hammer, O., Harper, D. A. T., \& Ryan, P. D. (2001). PAST: paleontological statistics software package for education and data analysis. Palaeontologia Electronica, 4(1), 1-9.

Hunke, P., Mueller, E. N., Schröder, B., \& Zeilhofer, P. (2015a). The Brazilian Cerrado: assessment of water and soil degradation in catchments under intensive agricultural use. Ecohydrology, 8(6), 11541180. http://dx.doi.org/10.1002/eco.1573.

Hunke, P., Roller, A., Zeilhofer, P., Schröder, B., \& Mueller, E. N. (2015b). Soil changes under different land-uses in the Cerrado of Mato Grosso, Brazil. Geoderma Regional, 4, 31-43. http://dx.doi.org/10.1016/j.geodrs.2014.12.001.

Indústria Brasileira de Árvores - IBÁ. (2020). Relatório 2020 (66 p.). Brasília: IBÁ. Retrieved in 2020, November 15, from https://iba.org/datafiles/publicacoes/relatorios/relatorio-iba-2020.pdf

Lima, E., Vitti, G. C., Santos, L. A., \& Cicarone, F. (2018). Cálcio e magnésio. In S. Fernades, S. R. Souza \& L. A. Santos. Nutrição mineral de plantas (pp. 465-490). Viçosa: Sociedade Brasileira de Ciência do Solo.

Lima, R. P., Fernandes, M. M., Fernandes, M. R. M., \& Matricardi, E. A. T. (2015). Aporte e decomposição da Serapilheira na Caatinga no Sul do Piauí. Floresta e Ambiente, 22(1), 42-49. http://dx.doi.org/10.1590/2179-8087.062013.

Lopes, E. S., Oliveira, D., Rodrigues, C. K., \& Drinko, C. H. (2015). Compactação de um solo submetido ao tráfego do Harvester e do Forwarder na colheita de madeira. Floresta e Ambiente, 22(2), 223-230. http://dx.doi.org/10.1590/2179-8087.046413.

Melillo, J. M., Aber, J. D., \& Muratore, J. F. (1982). Nitrogen and Lignin Control of Hardwood Leaf Litter Decomposition Dynamics. Ecology, 63(3), 621-626. http://dx.doi.org/10.2307/1936780.

Melos, A. R., Sato, A. M., \& Coelho Netto, A. L. (2010). Produção, estoque e retenção hídrica da serrapilheira em encosta sob plantio de híbridos de Eucalyptus urophylla e Eucalyptus grandis: Médio Vale do Rio Paraíba do Sul. Anuário do Instituto de Geociências, 2(2), 66-73.

Mendham, D. S., Ogden, G. N., Short, T., O'Connell, T. M., Grove, T. S., \& Rance, S. J. (2014). Repeated harvest residue removal reduces $E$. globulus productivity in the 3 rd rotation in south-western 
Australia. Forest Ecology and Management, 329, 279-286.

http://dx.doi.org/10.1016/j.foreco.2014.06.033.

Momolli, D. R., Schumacher, M. V., Dick, G., Vieira, M., \& Souza, P. H. (2018). Decomposition from leaf litter and nutrients release in Eucalyptus dunnii in the Pampa biome. Scientia Forestalis, 46(118), 199-208.

Neves, J. C. L., Barros, N. F., Novais, R. F., \& Anjos, J. L. (1982). Efeito do alumínio em amostras de dois latossolos de cerrado sobre o crescimento e absorção de nutrientes de mudas de Eucalyptus grandis. Revista Árvore, 6(1), 17-28.

Novais, R. F., Gomes, J. M., Rocha, D., Borges, E. E. L., \& Nascimento Filho, M. G. (1979). Calagem e adubação mineral na produção de mudas de eucalipto (Eucalyptus grandis W. Hill ex Maiden). efeitos da calagem e dos nutrientes N, P e K. Revista Árvore, 3(2), 121-134.

Olson, J. S. (1963). Energy storage and the balance of producers and decomposers in ecological systems. Ecology, 44(2), 322-331. http://dx.doi.org/10.2307/1932179.

Ramos, T. V., Santos, L. A. C., Souza, W. G., Souza, K. R., Lima, N. L., Guimarães, L. E., Brandão, D. C., Silva, J. P., Gonçalves, R. A., Gonçalves, B. B., Arruda, E. M., Calil, F. N., \& Silva-Neto, C. M. (2018). Chemical attributes of Brazilian Cerrado soil under different management systems. Australian Journal of Crop Science, 12(3), 505-510. http://dx.doi.org/10.21475/ajcs.18.12.03.pne1126.

Rawat, L., \& Singh, S. P. (1995). Litter decomposition and nitrogen concentration in decomposing leaves of a quercus seme-carpifolia smith forest stand of Kumaun Himalaya. Communications in Soil Science and Plant Analysis, 26(3-4), 411-424. http://dx.doi.org/10.1080/00103629509369307.

Ribeiro, F. C., Bussinguer, A. P., Hodecker, B. E. R., \& Gatto, A. (2017). Conteúdo de nutrientes na serapilheira em três fisionomias do cerrado do Distrito Federal. Pesquisa Florestal Brasileira, 37(92), 465-473. http://dx.doi.org/10.4336/2017.pfb.37.92.1312.

Rocha, J. H. T., Marques, E. R. G., Gonçalves, J. L. D., Hübner, A., Brandani, C. B., Ferraz, A. D. V., \& Moreira, R. M. (2016). Decomposition rates of forest residues and soil fertility after clear-cutting of Eucalyptus grandis stands in response to site management and fertilizer application. Soil Use and Management, 32(3), 289-302. http://dx.doi.org/10.1111/sum.12283.

Santos, M. F., Balieiro, F. C., Fontes, M. A., \& Chaer, G. M. (2018). Understanding the enhanced litter decomposition of mixed-species plantations of Eucalyptus and Acacia mangium. Plant and Soil, 423(12), 141-155. http://dx.doi.org/10.1007/s11104-017-3491-7.

Schumacher, F. X., \& Hall, F. S. (1933). Logarithmic expression of timber-tree volume. Journal of Agricultural Research, 47(9), 719-734.

Schumacher, M. V., \& Viera, M. (2015). Ciclagem de nutrientes em plantações de eucalipto. In M. V. Schumacher \& M. Viera. Silvicultura do Eucalipto no Brasil (pp. 273-307). Santa Maria: UFSM.

Schumacher, M. V., Corrêa, R. S., Viera, M., \& Araújo, E. F. (2013). Produção e decomposição de serapilheira em um povoamento de Eucalyptus urophylla x Eucalyptus globulus maidenii. Cerne, 19(3), 501-508. http://dx.doi.org/10.1590/S0104-77602013000300018.

Sousa, D. M. G., \& Lobato, E. (2004). Cerrado: correção do solo e adubação (416 p.). Planaltina: Embrapa Cerrados.

Suzuki, L. E. A. S., Lima, C. L. R., Reinert, D. J., Reichert, J. M., \& Pillon, C. N. (2014). Estrutura e armazenamento de água em um Argissolo sob pastagem cultivada, floresta nativa e povoamento de eucalipto no Rio Grande do Sul. Revista Brasileira de Ciência do Solo, 38(1), 94-106. http://dx.doi.org/10.1590/S0100-06832014000100009.

Tacca, D., Klein, C., \& Preuss, J. F. (2017). Soil arthropodofauna in a forest of eucalyptus and a remanescent of native forests in the south of Brazil. Revista Thema, 14(2), 249-261. http://dx.doi.org/10.15536/thema.14.2017.249-261.456.

Valadão, M. B. X., Carneiro, K. M. S., Inkotte, J., Ribeiro, F. P., Miguel, E. P., \& Gatto, A. (2019). Litterfall, litter layer and leaf decomposition in Eucalyptus stands on Cerrado soils. Scientia Forestalis, 46(121), 256-264. http://dx.doi.org/10.18671/scifor.v47n122.08.

Valadão, M. B. X., Carneiro, K. M. S., Ribeiro, F. P., Inkotte, J., Rodrigues, M. I., Mendes, T. R. S., Vieira, D. A., Matias, R. A. M., Lima, M. B. O., Miguel, E. P., \& Gatto, A. (2020). Modeling biomass and nutrients in a Eucalyptus Stand in the Cerrado. Forests, 11(10), 1-18. http://dx.doi.org/10.3390/f11101097.

Versini, A., Mareschal, L., Matsoumbou, T., Zeller, B., Ranger, J., \& Laclau, J. P. (2014). Effects of litter manipulation in a tropical Eucalyptus plantation on leaching of mineral nutrients, dissolved organic nitrogen and dissolved organic carbon. Geoderma, 232-234, 426-436. http://dx.doi.org/10.1016/j.geoderma.2014.05.018. 
Versini, A., Nouvellon, Y., Laclau, J. P., Kinana, A., Mareschal, L., Zeller, B., Ranger, J., \& Epron, D. (2013). The manipulation of organic residues affects tree growth and heterotrophic $\mathrm{CO}_{2}$ efflux in a tropical Eucalyptus plantation. Forest Ecology and Management, 301, 79-88. http://dx.doi.org/10.1016/j.foreco.2012.07.045.

Vieira, J. A. G., Teixeira, M. B., Loss, A., Lima, E., \& Zonta, E. (2009). Produção de Serapilheira e retorno de nutrientes ao solo pela espécie Eucalyptus urograndis. Revista Brasileira de Agroecologia, 4(2), 40-43.

Viera, M., Schumacher, M. V., \& Araújo, E. F. (2014). Disponibilização de nutrientes via decomposição da serapilheira foliar em um plantio de Eucalyptus urophylla x Eucalyptus globulus. Floresta e Ambiente, 21(3), 307-315. http://dx.doi.org/10.1590/2179-8087.066313.

Vilela, L., Sousa, D. M. G., \& Silva, J. E. (2004). Adubação potássica. In D. M. G. Sousa \& E. Lobato. Cerrado: correção do solo e adubação (pp. 169-183). Planaltina: Embrapa Cerrados.

Villalobos-Vega, R., Goldstein, G., Haridasan, M., Franco, A. C., Miralles-Wilhelm, F., Scholz, F. G., \& Bucci, S. J. (2011). Leaf litter manipulations alter soil physicochemical properties and tree growth in a Neotropical savanna. Plant and Soil, 346(1-2), 385-397. http://dx.doi.org/10.1007/s11104-011-0860-5.

Authors' contributions: MBXV, AG, EPM and FPR: conceptualization; MBXV., KMSC, FPR, Jl, MIR and BERH: Methodology; MBXV, KMSC, AG and EPM: formal analysis and investigation; MBXV: writing - original draft preparation; MBXV and FPR: writing - review and editing; MBXV, AG and EPM: supervision. All authors have read and agreed to the published version of the manuscript. 